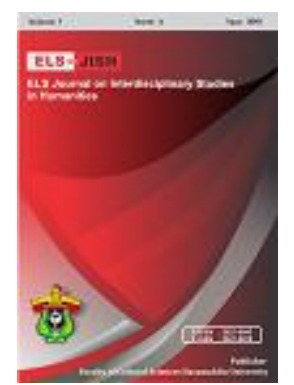

ELS-JISH

ELS Journal on Interdisciplinary Studies on Humanities

Volume 2 Issue 2, 2019

ISSN (print) : 2621-0843

ISSN (online) : 2621-0835

Homepage : http://journal.unhas.ac.id/index.php/jish

\title{
Investigating the meaning of Al-'ifk and Al-kadhib (Lie) and their English Translation by Abdullah Yusuf Ali
}

\author{
Abdul-Qader Khaleel Abdul-Ghafour ${ }^{1}$, Yasser Alrefaee ${ }^{2}$, Sameer Boset ${ }^{3}$, \\ Morshed S. Al-Jaro4 \\ 19abdul20003000@yahoo.com
}

\begin{abstract}

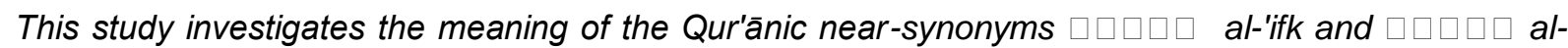
kadhib (lie) and their English translation. It aims to identify the contextual meaning of these Qur'ānic near-synonyms based on the exegeses of the Holy Qur'än. Then, it explains the nuances that exist between these two lexical items in terms of denotative meaning. This study also examines how the semantic differences between these Qur'ānic near-synonyms are reflected in the English translation of the Holy Qur'ān by Ali (2006). This study adopts the RC-S approach by Murphy (2003) as a theoretical framework for data analysis. It also employs the qualitative approach to collect and analyze the data of the study. The exegeses of the Holy Qur'ân are consulted to identify the semantic differences between the Qur'ānic near-synonyms. The findings reveal that there exist some differences in meaning between these Qur'änic near-synonyms in terms of denotative meaning and that the semantic differences between these Qur'ānic near-synonyms are not reflected in Ali's English translation of the Holy Qur'ān. The study provides recommendations for readers and translators especially the translators of the Holy Qur'ān.
\end{abstract}

Keywords: Contextual Meaning, Denotative Meaning, Synonymy, Qur'ānic Near-Synonyms, Translation.

How to cite: Abdul-Ghafour, et al. (2019). Investigating the meaning of Al-'ifk and Al-kadhib (Lie) and their English Translation by Abdullah Yusuf Ali. ELS Journal on Interdisciplinary Studies in Humanities, $2(2), 182-192$.

\section{Introduction}

The Holy Qur'ān includes many lexical items which have seemingly similar meanings but communicate different meanings upon deeper semantic analysis of the constituents of such lexical items items. There is a consensus among researchers that these lexical items are called near-synonyms (Al-Sowaidi, 2011). Scholars (e.g. Bint Al-Shațī, 1971; Omar, 2001) contend that the Qur'ānic synonyms are all considered near-synonyms; such near-synonyms refer to lexical items which share some but not all shades of meaning. More importantly, Al-Shacrāwī (1993) explains that every near-synonym in the Holy Qur'ān has its special meaning that cannot be conveyed by another in the same context. For instance, the Qur'ānic near-synonyms

1,2,3,4 Universiti Kebangsaan Malaysia (UKM), Malaysia 
اقسم halafa and 'aqsama (swore) have one general equivalent in English. However, there are some semantic differences between such near-synonyms in the Holy Qur'ān. Abu 'Udah (1985) points out that the near-synonym حلف halafa in the Holy Qur'ān means swore untruthfully and is used to implicate a false oath while اقسم 'aqsama means swore truthfully and implicates a true oath. However, both nearsynonyms are interchangeably employed in Modern Standard Arabic (i.e. the standardized variety of Arabic used in writing and formal speech throughout the Arab world to facilitate communication).

Another example of the Qur'ānic near-synonyms is the pair of العفو al-cafwa and al-maghfirah (forgiveness). Abdul-Ghafour et al (2017) explained the semantic differences between such Qur'ānic near-synonyms based on the exegeses of the Holy Qur'ān claiming that although both Qur'ānic near-synonyms share the core meaning 'forgiveness', the lexical item العفو al-cafwa might be associated with blame and rebuke while the other lexical item المغفرة al-maghfirah (forgiveness) is associated with the veil, encasement, and concealment of the sin. They added that the nuances between these Qur'ānic near-synonyms are not reflected in the English translation and these Qur'ānic near-synonyms are regarded as absolute near-synonyms (i.e. lexical items with identical meanings).

In fact, the subtle nuances between the Qur'ānic near-synonyms usually confuse both the reader as well as translator. If a translator could not realize such differences in meaning and misunderstand the original meaning, the Qur'ānic nearsynonyms will be misinterpreted and consequently the Qur'ānic message will not be appropriately conveyed. Newmark (1988), Abdullah (2003) and Ishrateh (2006) applaud that the semantic differences between near-synonyms are contextdependent and consequently the context should be analyzed so as to provide an appropriate translation for near-synonyms. In addition, the exegeses of the Holy Qur'ān play a great role in explicating the differences in meaning between the nearsynonyms and consequently facilitate their translation. Therefore, the Qur'ānic nearsynonyms will be studied and analyzed in their Qur'ānic contexts and the exegeses of the Holy Qur'ān will be consulted to account for the nuances between the Qur'ānic near-synonyms and how such nuances are reflected in the English translation.

\section{Problem Statement}

The Qur'ānic near-synonyms have special features which make mapping their meanings onto another language highly problematic. Ali (1938) confirms that the Qur'ānic vocabulary is so rich that it gives special words for similar ideas and things which have only a general word in English. Moreover, it is claimed that although some near-synonyms are utilized interchangeably in Modern Standard Arabic, they are used differently in the Holy Qur'ān (Al-Sowaidi, 2011). An example of such Qur'ānic near-synonyms is the Qur'ānic pair العبيد al-cabìd and العباد al-cibād which mean the slaves in English. However, each one of such near-synonyms has its specific meaning in the Holy Qur'ān and most importantly they cannot be used interchangeably. Issa (2011) claims that Al-Shacrāwī (1991) explains the differences in meaning between such near-synonyms by saying that العبيد al-cabīd (the slaves) refers to "all creatures of Allah, as all of them are created by Him and unwilling to act against His Laws, while the other lexical item العباد al-cibād (the slaves) is specifically used when the context is referring to the believers in Allah who obey all His orders with will and choice" (p. 32). 
In fact, the nuances between these Qur'ānic synonyms are vitally significant to perceive the meanings of the Qur'ānic texts. If the nuances between the Qur'ānic near-synonyms are not conveyed to the reader, the Qur'ānic text will not be appropriately understood. This study identifies the contextual meaning of the Qur'ānic near-synonyms الكذب al-'ifk and الإفلك al-kadhib (lie) based on the exegeses of the Holy Qur'ān. Then, it highlights the semantic differences between such Qur'ānic nearsynonyms and how the nuances between such Qur'ānic near-synonyms are reflected in Ali's (2006) English translation. This study provides the readers and translators with a deeper look into the subtle nuances between the Qur'ānic near-synonyms and how such nuances should be taken into account while translating the Qur'ānic nearsynonyms.

\section{Objectives of the study}

The present study aims at achieving the following study objectives:

a. To identify the contextual meanings of the Qur'ānic near-synonyms الإفلك al-'ifk and الكذب al-kadhib (lie).

b. To compare the meanings of the Qur'ānic near-synonyms الإفلك al-'ifk and al-kadhib (lie).

c. To explain how the nuances between the Qur'ānic near-synonyms الإقلك al-'ifk and الكنب al-kadhib (lie) are reflected in Ali's (2006) English translation of the Holy Qur'ān.

\section{Theoretical Framework}

The study adopts the Relation by Contrast Approach to Synonyms (RC-S) by Murphy (2003). This approach explains synonymy relation in terms of the minimal differences that exist between the pairs of synonyms. In this respect, Murphy argues that in any set of different forms of words which have similar denotations, there exists a slight difference in denotative and/or expressive meaning. Consequently, the semantic differences between synonyms can be explained in respect of the suggested parameters:

\section{Denotative meaning}

Denotation refers to "the relationship between sense and reference, and the sense of a word is the set of conditions on the word's reference" (Murphy, 2003, p. 148). Murphy states that the near-synonyms punish, correct, discipline, castigate and penalize have differences in denotation.

\section{Expressive elements of meaning}

Expressive meaning includes affective meaning, connotative meaning, and other social information that gives denotatively similar words different significance without affecting their contributions to sentential truth-conditions (Murphy, 2003).

a. Connotation is viewed as "the additional meanings that a word or phrase has beyond its central meaning" (Richards \& Schmidt, 2002, p. 108). It involves associations which do not directly affect the conditions on reference, but which may give some slant to the description (Murphy, 2003).

b. Affect is a non-denotative meaning which is concerned with the speaker's attitude toward the subject at hand (Murphy, 2003). 
c. Social information: Other aspects of social meaning include dialect, register, jargon, and other sub-varieties of a language or vocabulary (Murphy, 2003).

This approach is adopted for the current study because it provides a framework for analyzing the nuances between the near-synonyms in question. In the light of the RC-S approach, the researchers will analyze the meaning of the Qur'anic nearsynonyms and explain how the nuances between the selected Qur'ānic nearsynonyms are reflected in the English translation.

\section{Literature Review}

Scholars (Bint Al-Shātī, 1987; Omar, 2001) assert that the Qur'ānic nearsynonyms refer to lexical items which share some but not all shades of meaning. Literature reveals that 'near-synonyms' is the term preferred by most Arab and nonArab linguists when it comes to the Qur'ānic synonyms (Abdellah, 2003). The reason why the Qur'ānic synonyms are regarded as near-synonyms is justified by many linguists as well as scholars. It is claimed that the plentiful occurrence of the absolute synonyms (i.e. lexical items with identical meaning) in the Holy Qur'ān contradicts the fact that the Qur'ānic words are chosen carefully to convey exact meanings whether denotative or expressive (Hassan, 2014). Moreover, the scholars who confirm that the occurrence of absolute synonyms in Arabic reject the idea of the prevalence in the Holy Qur'ān since this is probably to mess up its uniqueness and excellence (ibid). The advocates of this view are Ibn Taymīyah, Al-Rāghib Al-Asfahānī, Ibn Ațiyah, Al-Tabarī, Ibn Kathīr, Al-Shāyic, Al-Khatābi, Al-Qurțubī, Bint Al-Shāțī' and AlSayuțī (cited in Al-Shāyic, 1993).

Al-'Uwa (1998) investigated synonyms and the differences between them in the Holy Qur'ān claiming that even though there is synonymy in Arabic, the Qur'ānic language should be particularly dealt with differently. In this connection, Abū 'Udah (1985) maintains that absolute synonymy does exist in literary texts within limits. However, such a phenomenon does not exist in the Holy Qur'ān. In the same vein, Al-Zamakhsharī (2009) denies the concept of absolute synonymy in the Holy Qur'ān and made a distinction between حزن حزن huzn and بث bath (sadness). It is claimed that

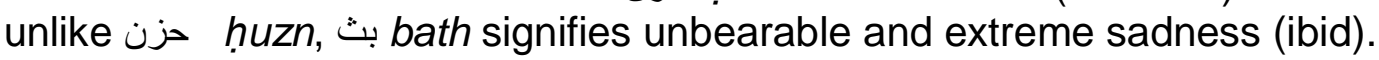

Furthermore, it is argued that every lexical item of the Qur'ānic synonyms has its special meaning that cannot be conveyed by another even if the two lexical items sound similar (Al-Sha'rāwī, 1993). What exist in the Holy Qur'ān are simply nearsynonyms which seem to be synonymous but convey different semantic meanings upon deeper semantic analysis of the items which are generally considered to be synonymous at the surface (Al-Omari \& Abu-Melhim, 2014). This conclusion is substantiated by clear evidence drawn from a number of explications of the Holy Qur'ān carried out by qualified Muslim scholars and professional Arab linguists (ibid).

Moreover, Bint Al-Shāțī' (1971) points out that the every phonemically different word in the Holy Qur'ān has its particular function at various levels of meaning or usage in a certain context. She also argues that the choice of lexical items in the Holy Qur'ān is mainly based on the context and thus replacing a lexical item by another never achieves all different aspects of uses and senses of the original text. That is why the translation of the Holy Qur'an is not dealt with as Qur'ān but rather as the translation of the meanings of the Holy Qur'ann perceived by the translator (Bint Al-Shāțī', 1971). 
In this regard, research reveal that absolute synonyms in the Holy Qur'ān are by no means an illusion and could be nonexistent at all. If the absolute synonymy exists among different lexical items, it means that the text can be understood by different people in different ways in accordance with the senses as well as the connotations aroused in the mind on the basis of the free substitution of similar other words (Abdellah, 2003). This is one reason why the advocates of differences fiercely defend their stand so as to protect the Holy Qur'ān from being misinterpreted on the basis of such substitutions.

On the basis of the above arguments, it seems that each lexical item of the Qur'ānic synonyms has a specific meaning and might be impossible to find a lexical item which directly and faithfully translates it into another language. This issue would be more difficult when it comes to translating the lexical items of a sacred text like the Holy Qur'ān. The terms provided by translators might communicate unneeded semantic differences or might ignore desired ones and thus the original message would be distorted. In other words, a full match between the target text and the source text might not be possible in different situations and therefore "faithful translation will require covering the differences in meaning conveyed by a source lexical item and then determining how the semantic differences can be conveyed in the target language by appropriate word choices in any particular context" (Edmonds, 1998, p. 23). In this respect, Issa (2011) argues that the slight semantic differences that exist between the pairs of Qur'ānic near-synonyms are of vital importance to perceive the miracles of the Holy Qur'ān as a religious book with unique features.

The current study argues that there exist subtle semantic differences between Qur'ānic near-synonyms which are difficult to grasp and such delicate semantic differences need a lot of consideration. This study might bring the meaning as well as the translation of near-synonyms of the Holy Qur'an into focus in the hope that their meaning would be clearer to the reader and the translator, and the translation of such near-synonyms, in turn, would be more appropriate in future translation.

\section{Methodology}

This study employs the qualitative approach to collect and analyze the data of the study because it is more relevant and helpful in explaining the nuances between the selected Qur'ānic near-synonyms. It also makes use of qualitative content analysis because it is a flexible method to analyze the data of the study. This study adopts Ali's (2006) translation of Holy Qur'ān; this translation is particularly selected for several reasons. First, Ali's translation is a well known English translation of the Holy Qur'ān in terms of its relative accuracy (Kideai, 1998) and has been successful to a certain extent in conveying the meaning of the Qur'anic texts (Al-Badani, 2015). Second, it is claimed that it is cited extensively in the literature and quoted monthly in the World League Journal issues in its feature entitled 'Guidance from the Glorious Qur'ān' (Khan, 2008). Third, this translation of the Holy Qur'ān is commonly used by many Muslims in that it is eloquent, modern and clear (Al-Badani, 2015). Fourth, it is regarded as the most recognized and authentic English translation of the Holy Qur'ān (Khan, 1997).

Moreover, this study heavily relies on many prominent exegeses of the Holy Qur'ān, Arabic and English dictionaries, and commentary books. The exegeses of Ibn ${ }^{\mathrm{C}} \bar{A}$ shur (1984) and Al-Shac ${ }^{C}$ āwī (1991) are selected because the exegetes worked on 
explaining the nuances between the Qur'ānic near-synonyms. Other exegeses like Al-Ṭabarī (2001), Al-Zamakhsharī (2009), Al-Qurțubī (2006), Al-Mahallī and AlSuyyutī (2003), Al-Alusī (1995) and Ibn Kathīr (1999) are also consulted because they are regarded as the most prominent exegeses of the Holy Qur'ān as maintained by (Abdul-Raof, 2001).

\section{Analysis of Data}

\subsection{The analysis of the Qur'ānic pair الإفلك al-'ifk and الكنب al-kadhib (lie)}

This section presents the analysis of the Qur'ānic pair الإقلك al-kadhib (lie).

\subsubsection{The contextual meanings of الإفلك al-'ifk and الكنب al-kadhib (lie)}

The contextual analysis of the Qur'ānic near-synonyms الكنب al-kifk and الإفلك al-kadhib (lie) reveals that there exist some semantic differences between these Qur'ānic nearsynonyms in terms of denotative meaning. This section discusses the contextual meanings of the Qur'ānic pair of near-synonyms based on the exegeses of the Holy Qur'ān. Here is the contextual analysis of the Qur'ānic verses:

Table 1: The meaning of الإفلك al-'ifk (lie)

\begin{tabular}{|c|c|}
\hline The Qur'anic verse & Its translation by Ali (2006) \\
\hline 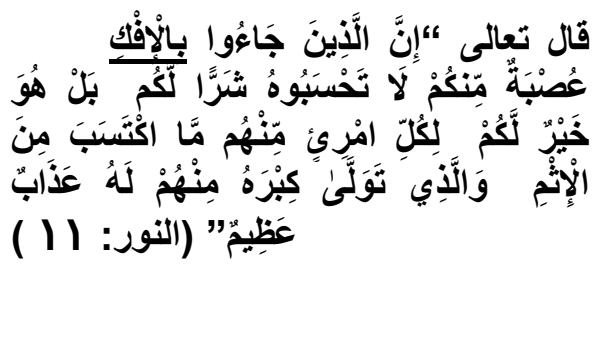 & $\begin{array}{l}\text { "Those who brought forward the lie are a body } \\
\text { among yourselves: think it not to be an evil to } \\
\text { you; On the contrary it is good for you: to every } \\
\text { man among them (will come the punishment) of } \\
\text { the sin that he earned, and to him who took on } \\
\text { himself the lead among them, will be a penalty } \\
\text { grievous" (Al-Nur: 11) }\end{array}$ \\
\hline
\end{tabular}

This verse is concerned with the lie of the hypocrites in the era of the Prophet Mohammed. The meaning of this verse is analyzed here in order to identify the meaning of the Qur'ānic near-synonym الِّفْفْكِ al-'ifk (lie). Ibn Al-Jawzī (2002) confirms that almost all exegetes agree that this verse was revealed about the story of Aisha, the wife of the Prophet Mohammed (May Allah be well pleased with her). This verse is interpreted by Al-Ṭabarī (2001), Al-Maḥallī and Al-Sayyūți (2003) as follows: Those who spread the slander (i.e. the fornication accusation of Aisha) are a band from among the believers. In this regard, Al-Shacrāwī (1991) points out that since they are cusbatun (a band), it means that they have a shared intention which is to destroy the good opinion that the people have about the Prophet Mohammed and his family. It is also stated that those who accused Aisha of fornication are four people, namely, Abdullah Bin Ubay (the hypocrite), Hassan Bin Thabit, Mistah Bin Uthathah and Hamnah Bint Jahsh. In fact, this verse was revealed upon the Prophet Mohammed to reveal the innocence of the wife of the Prophet Mohammed, Aisha, and also the innocence of Safwan Bin Al-Muattal, the one who was falsely accused of committing what is said in the slander.

In terms of the meaning of the lexical item الإفلك al-'ifk (lie), Al-Zamakhsharī (2009) explains that it is a special kind of الكذب al-kadhib (lie). It is a slander and is derived from إفلك 'ifk i.e. overturning the facts (Ibn ' ${ }^{\mathrm{l}}$ Ashūr, 1984 and Al-Zamakhsharī, 2009). Ibn 'Ashūr (1984) also states that الإقلك al-'ifk means a lie which has no 
suspicion. It is a slander that shocks people (ibid). Besides, Ibn Kathīr (1999) explains that الإفلك al-'ifk is a lie, slander and falsehood. Moreover, Al-Alūsī (1995) claims that الإفلك al-'ifk is the most blatant type of lies and slanders, and is often interpreted as absolute lying.

Al-Sha'rāwī (1991) explains that الكذب al-kadhib (lie) might be deliberate or indeliberate; if it is deliberate, then it is 'إفكا (lie) but if it is indeliberate, it is kadhib (lie). Hence, Al-Shacrāwī (1991) points out that li al-'ifk means a deliberate lie. In this verse, it is revealed that this Qur'ānic lexical item al al-'ifk (lie) is particularly selected to denote the slander against Aisha, the wife of the Prophet Mohammed to convey a certain Qur'ānic message (i.e. this lie is blatant and dangerous). The next verse will be analyzed in order to understand the meaning of the other near-synonym الكنب al-kadhib (lie) and how it is semantically different from الإفك al-'ifk (lie).

Table 2: the meaning of الكذب al-kadhib (lie)

\begin{tabular}{|c|c|}
\hline The Qur'anic verse & Its translation by Ali (2006) \\
\hline \multirow[t]{2}{*}{ 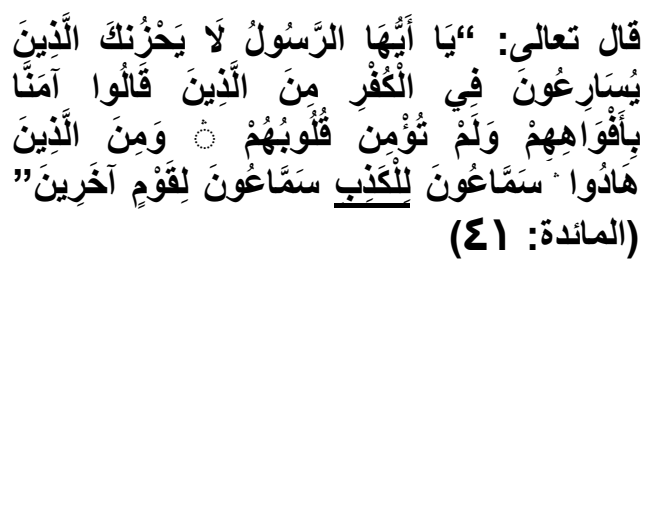 } & $\begin{array}{l}\text { "Messenger. let not those grieve thee, } \\
\text { who race each other into unbelief } \\
\text { (whether it be) among those who say "We } \\
\text { believe" with their lips but whose hearts } \\
\text { have no faith; or it be among the Jews,- } \\
\text { men who will listen to any lie, will listen } \\
\text { even to others who have never so much } \\
\text { as come to thee" }\end{array}$ \\
\hline & 'Imrān: \\
\hline
\end{tabular}

The meaning of this verse is analyzed in order to identify the meaning of the Qur'ānic near-synonym الكذب al-kadhib (lie). This verse is interpreted by Al-Tabari (2001), and Al-Mahallī and Al-Sayyūțī (2003) as follows: O Messenger Mohammed, do not let the actions of those who vie with each other in disbelief make you sad, those who manifest it at every opportunity. Al-Ṭabarī (2001) acknowledges that the Arabic lexical item sina (who) is semantically linked to the verb I قu qālu (say); say with their tongues (their mouths): we believe in Allah but their hearts do not actually believe i.e. they are hypocrites; among those are Jewish people, the inhabitant of (Khaybar) who come to you, the Prophet Mohammed. They, the Jewry, listen to falsehood (concerning the penalty of married people who commit adultery) fabricated by their rabbis; they are listeners on behalf of other folk who have not come to you; two married inhabitants of خيير (Khaybar) committed adultery but they wanted to escape from stoning and thus sent others to ask the Prophet Mohammed about the penalty regarding the commitment of adultery by the married people.

Ibn 'Ashūr (1984) argues that the lexical item سمَّاع sammāc (listen) means to eagerly listen to something (lies in this verse). Moreover, Al-Shacrāwī (1991) explains that سمَّاع sammāc (listen) in this verse implicates listening and believing lies simultaneously. He adds that the lexical item sammañ $\bar{a}^{c}$ (listen) is different from the lexical item يسمع yasmac (listen) claiming that the lexical item سمّاع sammāa (listen) is sighat mubālaghah (an exaggerative form) of بيغة مبالغة yasma (listen) in 
Arabic and thus it is specifically used to convey a certain message. Ibn 'Ashūr (1984) and Al-Shacrāwī (1991) claim that this lexical item, سمَّاع sammāc (listen), is purposefully used in this verse to denote the spread of lying among the hypocrites. To conclude, it is crucial to indicate that Al-Tabari (2001) points out that this verse was revealed upon the Prophet Mohammed to inform him not to grieve for the actions of hypocrites who pretend that they believe you while they do not and those Jewry who disbelieve your Prophethood.

\subsubsection{The semantic differences between الإفلك al-'ifk and الكنب al-kadhib (lie) based on RC-S Approach}

As seen in the contextual analysis of the meanings of the two Qur'annic nearsynonyms, there are some semantic differences between the two near-synonyms al-kadhib (lie) in terms of denotative meaning. The semantic differences between the two Qur'annic near-synonyms are explained here in the light of the parameters mentioned by Murphy (2003).

The data analysis reveals that الإقلك al-'ifk (lie) is more specific than الكنب alkadhib (lie). It is revealed that الإقإقك al-'ifk (lie) is derived from i.e. overturn the facts and is the most blatant and dangerous type of lies. It is also disclosed that it is deliberately invented to harm others. However, الكنب al-kadhib (lie) is more general than الإقإق al-'ifk (lie) and can be either deliberate or indelibrate. Moreover, Al-Sejestani (1963) confirms that الإقإl al-'ifk (lie) is worse than al-kadhib (lie). Besides, AlAskarī (1997) made a distinction between الإقإقك al-'ifk (lie) and الكذب al-kadhib (lie) claiming that the lexical item الكنب al-kadhib (lie) is more general than الإقلك al-'ifk (lie) in that الكنب al-kadhib (lie) can be offensive or inoffensive while الإقاك al-ifk (lie) is only offensive such as the lies about God, the Prophet, the Holy Qur'ān or the defamation of chaste women.

\subsubsection{The translations of الإفل al-'ifk and الكنب al-kadhib (lie)}

As revealed in the contextual analysis, الإقلك al-'ifk (lie) is more specific than al-kadhib (lie) and is deliberately invented to harm others (i.e. the Prophet and his family in this verse). It is noticed that these Qur'ānic near-synonyms are dealt with as absolute near-synonyms in that both near-synonyms are rendered as 'lie' and thus the semantic differences between them are not reflected in Ali's (2006) translation of the Holy Qur'ān. In fact, some other translators (such as Irving, 2002 and Arberry, 2003) provide a good rendition of the Qur'ānic near-synonym الإقإlifl'ifk (lie) and translate this lexical item as 'slander'. Translating the Qur'ānic near-synonym الإقل al'ifk (lie) as 'slander' reflects the semantic differences between the two lexical items الإفلك al-'ifk (lie). In English, the lexical item 'slander' means "a false spoken statement about someone, intended to damage the good opinion that people have of that person" (Longman Dictionary of Contemporary English, 2007). This lexical item can be equivalent to the Qur'ānic lexical item الإفإlal-'ifk (slander) which is purposefully used in the verse to show the danger of such a kind of lies.

In addition, it is noteworthy that the intended meaning of the lexical item سمَّاعون sammācuna is not reflected in English translation of Ali (2006); this lexical item is rendered as 'listen' and thus the Qur'ānic message (i.e. the spread of lies) is not conveyed. This lexical item is an exaggerative form صيغة مبالغة sighat mubālaghah (an exaggerative form) of بسمع yasma (listen) and is specifically used to implicate the spread of lies among the hypocrites. Therefore, it would have been better had the 
translators render the lexical item سمَّاعون sammācuna as "ever/eagerly listen" in this verse. This translation sounds more faithful and reflects the intended meaning of the Qur'ānic lexical item, سمَّاعون sammācuna, in the Qur'ānic verse.

\section{Conclusion}

It is crucial to indicate that the Qur'ānic texts are different from all other texts written by humankind as it is revealed by Allah in Arabic language. Every Qur'ānic lexical item is purposefully chosen to convey a certain meaning and thus replacing a Qur'ānic lexical item by another does not convey the intended meaning in that context. The present study reveals that the nuances between selected nearsynonyms do exist which are difficult to understand even for the native speakers of Arabic. Such differences in meaning must be taken into account while translating Qur'ānic near-synonyms. Therefore, this study recommends that the translators of the Holy Qur'ān should pay much more attention to the semantic differences between the Qur'ānic near-synonyms. They should identify the nuances between the Qur'ānic near-synonyms and make sure that such semantic differences are reflected in their translations. Moreover, it is revealed the context of verses in which the Qur'ānic nearsynonyms are used plays an important role in explicating the differences in meaning between the Qur'ānic near-synonyms. Consequently, the translators of the Holy Qur'ān should carry out a contextual analysis of the Qur'ānic verses in order to identify the semantic differences between near-synonyms before the translation takes place. Readers and translators should also look for the semantic differences between the Qur'ānic near-synonyms whenever they find two near-synonyms with seemingly synonymous meanings so as to understand the Qur'ānic message appropriately. Besides, they should consult the exegeses of the Holy Qur'ān since they clearly explicate the Qur'ānic lexical items as well as texts. In particular, translators should deeply delve in the exegeses of the Qur'ānic verses in which the Qur'ānic near-synonyms are employed. Then, they should do their best to convey the nuances between the Qur'ānic near-synonyms in their translation. In terms of future research, literature (e.g. Abdul-Ghafour et al, 2019) reveals that there are a few studies which investigated the Qur'ānic near-synonyms and how the nuances between such near-synonyms are reflected in translation. Much research is, thus, needed to investigate the translation of the near-synonyms particularly in the Holy Qur'ān as it is a significant religious book for all Muslims all over the world.

\section{References}

Al-Badani, N. A. A. (2015). The translation of Iltifāt in Surat Al-Baqarah: Implicatures and strategies. Unpublished PhD thesis. Malaysia: Universiti Kebangsaan Malaysia.

Abdellah, A. (2003). Translations of near-synonyms in the Qur'ān: A context-based analysis. Unpublished master's thesis. London: University of London.

Abdul-Ghafour, A. K. M., Awal, N. M., Zainudin, I. S., Aladdin, A. (2017). Meanings of Near-Synonyms and Their English Translation Issues in the Holy Qur'ān. GEMA Online Journal of Language Studies. Vol. 17(4), 258-273.

Abdul-Ghafour, A. K. M., Awal, N. M., Zainudin, I. S., Aladdin, A. (2019). The Interplay of Qur'ānic synonymy and polysemy with special reference to Al-asfār 
and Al-kutub (the books) and their English translations. 3L: The Southeast Asian Journal of English Language Studies, Vol 25(1): 129 - 143.

Ali, A.Y. (2006). The Meaning of the Noble Qur'ān. www.holybooks.com

Abdul-Raof, H. (2001). Qur'an Translation: Discourse, Texture and Exegesis. Britain: Curzon Press.

Abu Udah, K. (1985). Al-tațawur Al-dalālī Baīn Lughat Al-shicr Al-jāhilī wa Lughat AlQur'ān Al-Karīm: Dirāsah dalāliyyah. Al-Zarqā: Al-Manār Library.

Al-Alusī, S. M. (1995). Ruh Al-Māānī fī Tafsìr Al-Qur'ān Al-cazìm wa Al-Sabcu AlMathānī. Beirut: Dar Al-Kutub Al-Elmīah.

Al-c'Askarī, A. (1997). Mucjam Al-Furūq Al-Lughawyyah. Mohamed Ibrahim Salim (Ed.). Cairo: Dar Al-cllm Wa Al-Thaqāfah.

Ali, A.Y. (1938). The Holy Qur'ān: Text, Translation and Commentary. Lahore: Sh. Muhammad Ashraf Publishers.

Al-Mahallī, G. \& Al-Sayutī, G. (2003). Tafsīr Al-Jalālaīn. Lebnon: Nashroon Publishers.

Al-Makhzūmī, Mujāhid Bin Jabr (1989). Tafsīr Mujāhid. Mohammed Abdul-Salam Abu Alnil (Ed.). Egpyt: Dār Al-Fikr Al-Islāmī. www.shamela.ws.

Al-Omari, S. K. \& Abu-Melhim, A. R. H. (2014). Synonymy in English and Arabic with Reference to the Holy Qur'an: A Contrastive Study. Theory and Practice in Language Studies, 4(12), 2619-2626.

Al-Qurțubī, A. A. (2006). Al-Jamecu Li Aḥkām Al-Qur'ān. Beruit: Al-Resalah Publishers.

Al-Sejestānī, A. M. (1963). Gharīb Al-Qurān. Cairo: Maktabat wa Matbaat Mohammed Ali Subayh.

Al-Shacrawī, M. M. (1991). Tafsīr Al-Shacrawī. Cairo: Bookshops and Books Management.

Al-Shacrawī, M. M. (1993). Múcjizāt Al-Qur'ān. Cairo: Bookshops and Books Management.

Al-Shāyic, M. (1993). Al-furūq Al-lughawiyyah wa 'ātharuha Aī Tafsīr Al-Qur'ān AlKarīm. Riyad: Al-Ukayban Library.

Al-Sowaidi, B. S. (2011). Textuality in Near Synonyms Translations of the Holy Qur'ān into English. PhD thesis, Univeristy of the Western Cape.

Al-Tabarī , J. M. (2001). Tafsīr Al-Tabarī : Jamicu Al-Bayān can Ta'wīl Ay Al-Qur'ān. Cairo: Dār Al-Macrefah.

Al-`CUwa, S. (1998). Al-wujūh wa Al-nazāāir fĩ Al-Qur'ān Al-Karīm. Cairo: Dār al-Sharq.

Al-Zamakhsharī, A. (2009). Al-Kash-shāf can Haqāiq Ghawāmiọ Al-Tanzīl. Beirut: Dār Al-Macrefah.

Arberry, A. J. (2003). The Koran interpreted. London: Allen \& Unwin.

Bint Al-Shațī, A. A. (1971). Al-Icjaz Al-bayānī lil-Qur'ān wa masā'el Ibn Al-Azraq. Cairo : Dar Al-Macāref. 
Edmonds, P. 1998. Translating near-synonyms: Possibilities and preferences in the interlingua. Proceedings of the AMTA/SIG-IL Second Workshop on Interlinguas, Langhorne, 23-30.

Hassan, A. E. (2014). Readdressing the Translation of near-Synonym in the Glorious Qura'n. European Scientific Journal. Vol. 10(8), 165-191.

Ibn Al-Jawzī, G. A. (2002). Zād Al-Masìr fi cllm Al-Tafsīr. Beirut: Dar Al-Ketab AlArabi.

Ibn ${ }^{\circ}$ Āshur, M. A. (1984). Tafsīr Al-Tahrīr wa Al-Tanwīr. Tunisia: Al-Dar Al-Tunesīah Publishers.

Ibn Kathīr, I. O. (1999). Tafsïr Al-Qur'ān Al-Azīm. Riyadh: Dar Ṭaibah.

Irving T. B. (2002). The Qur'ān: The first American version. Retrieved from http://almubin.tripod.com/irving.htm

Ishrateh, M. (2006). The Translatability of Cognitive synonyms in Shakespeare's Macbeth: A comparative/Contrastive Study. Unpublished MA thesis, An-Najah University, Palestine.

Issa, H. (2011). Textuality-mediated Synonymy in English/Arabic Translation. Unpublished MA thesis: American University of Sharjah.

Khan, M. (1997). English translation of the Holy Qur'an: a biography study. Tokyo: Toppan Company.

Kidwai, A. (1998). Translating the untranslatable: a survey of English translations of the Qur'an. The Muslim World Book Review. New York: Oxford University Press.

Murphy, M. L. (2003). Semantic relations and the lexicon: Antonymy, synonymy and other paradigms. New York: Cambridge Univeristy Press.

Longman Dictionary of Contemporary English (6th edition) (2007). Harlow: Pearson Education Ltd.

Newmark, P. (1988). A Textbook of Translation. Singapore: Prentice Hall.

Omar. A. M. (2001). Drasat Lughawyah fi Al-Qur'ān Al-Karīm wa Qirā'atih. Cairo: ${ }^{c}$ Ālam Al-Kutub

Richards, J. C. \& Schmidt, R. (2002). Longman Dictionary of Language Teaching and Applied Linguistics (3rd ed.). London: Pearson Education Limited. 